\title{
MicroRNA analysis in human papillomavirus (HPV)-associated cervical neoplasia and cancer
}

\author{
Amy S Gardiner ${ }^{1 *}$, William C McBee Jr. ${ }^{2}$, Robert P Edwards², Marshall Austin² ${ }^{2}$ Jamie L Lesnock², Rohit Bhargava ${ }^{3}$, \\ Richard Guido², Saleem A Khan ${ }^{1}$ \\ From $12^{\text {th }}$ International Conference on Malignancies in AIDS and Other Acquired Immunodeficiencies \\ (ICMAOI) \\ Bethesda, MD, USA. 26-27 April, 2010
}

MicroRNAs (miRNAs) are $22 \mathrm{nt}$ single-stranded, nonprotein-coding RNAs that generally negatively regulate their target mRNAs at a posttranscriptional level. Differential expression of miRNAs has been observed in many human cancers. To study their potential role in the pathogenesis of human papillomavirus (HPV) type 16associated cervical neoplasia and cancer, we analyzed miRNA expression in cervical tissue from the normal cervix, moderate/severe dysplasia, and invasive squamous cell carcinoma. Using RNA from 6 cervical cancers, 3 dysplasias, and 4 normal samples and the TaqMan ${ }^{\circ}$ MicroRNA Arrays, we found that 18 miRNAs were overexpressed and 2 underexpressed in cervical cancer compared to the normal cervical tissue $(\mathrm{p}<0.05)$. We further found that 9 miRNAs (miRs-16, 21, 106b, 124, 135b, 223, 301b, 449a, and 141) were consistently overexpressed and 2 miRNAs (miRs-218 and 433) were consistently underexpressed in cervical cancer compared to the normal tissue. MiRNA expression in dysplasia samples was most similar to the normal tissue, with the exception of the overexpression of miR-16, miR-141, and miR-449a, and the underexpression of miR-218 and miR-433. Our results suggest that five miRNAs may have potential as markers for progression of dysplasia to invasive cervical disease.

\section{Acknowledgements}

This article has been published as part of Infectious Agents and Cancer Volume 5 Supplement 1, 2010: Proceedings of the $12^{\text {th }}$ International Conference on Malignancies in AIDS and Other Acquired Immunodeficiencies (ICMAOI). The full contents of the supplement are available online at http://www.biomedcentral.com/1750-9378/5?issue=S1.

*Correspondence: asg18@pitt.edu

${ }^{1}$ Department of Microbiology and Molecular Genetics, University of

Pittsburgh School of Medicine, Pittsburgh, PA, USA

Full list of author information is available at the end of the article

\section{Author details}

${ }^{1}$ Department of Microbiology and Molecular Genetics, University of Pittsburgh School of Medicine, Pittsburgh, PA, USA. ${ }^{2}$ Division of Gynecologic Oncology, Department of Obstetrics, Gynecology, and Reproductive Sciences, Magee-Women's Hospital of the University of Pittsburgh Medical Center, Pittsburgh, PA, USA. ${ }^{3}$ Department of Pathology, Magee-Women's Hospital of the University of Pittsburgh Medical Center, Pittsburgh, PA, USA.

Published: 11 October 2010

doi:10.1186/1750-9378-5-S1-A55

Cite this article as: Gardiner et al:: MicroRNA analysis in human papillomavirus (HPV)-associated cervical neoplasia and cancer. Infectious Agents and Cancer 2010 5(Suppl 1):A55.
Submit your next manuscript to BioMed Central and take full advantage of:

- Convenient online submission

- Thorough peer review

- No space constraints or color figure charges

- Immediate publication on acceptance

- Inclusion in PubMed, CAS, Scopus and Google Scholar

- Research which is freely available for redistribution

Submit your manuscript at www.biomedcentral.com/submit
C Biomed Central 